UDK 821.111'02-131.09

\title{
THE EXPLOITATION OF HEROIC CONVENTIONS IN THE OE POEM ANDREAS: AN ARTISTIC MISCONDUCT OR A CONVINCING BLEND OF TRADITIONAL LITERARY CONCEPTS AND NEW CHRISTIAN IDEAS?
}

\author{
Alenka Divjak
}

\begin{abstract}
This paper examines the function of traditional heroic concepts, typical of the traditional military Germanic society, in the Christian environment of the Old English poem Andreas, whose indebtedness to the traditional heroic poetry has been generally recognised. The paper juxtaposes four examples of traditional heroic ethos from Beowulf, the most detailed example of heroic poetry, and the text to which Andreas is verbally and stylistically very close, with the relevant parallels from Andreas, in order to determine to what extent the traditional images relating to the life of traditional heroic society still retain in Andreas their traditional connotations and to what extent they are imbued with the new Christian meaning.
\end{abstract}

Key words: the saint's life, traditional military endeavours versus spiritual heroism, the concept of exile, the comitatus relationship, hall-life, conversion

\section{INTRODUCTION}

St Andrew, the first apostle to be summoned by Jesus, has always been regarded as one of the most influential saints in Western and Eastern Christendom alike. His cult occupied an important position in Anglo-Saxon England as well, as evidenced in the number of churches dedicated to him, Latin calendars and martyrologies, hymns, and homilies (Walsh, 101), while his popularity among the laity is attested by the Old English poem Andreas, and two shorter prose texts, Blicking Homily 19 and Ælfric's Catholic Homily I. 38. Andreas is an account of the saint's missionary activity in the pagan land of Mermedonia, Blicking Homily 19 recounts the same event as Andreas, and Ælfric's Catholic Homily I. 38 records Andrew's martyr's death in Patras, Greece. Of these vernacular accounts, Andreas has been most widely discussed, receiving a significant amount of scholarly attention since its first publication in 1840 by Jacob Grimm. ${ }^{1}$

\footnotetext{
${ }^{1}$ Other editions of Andreas were published in the following order: in 1843 by John Kemble, in 1883 by Richard Wülker, in 1885 by William Baskerville, in 1906 and 1932 by George Krapp, and in 1961 by Kenneth Brooks.
} 
A considerable portion of St Andrew's fame is based on his reputation as a fartraveller as he is believed to have travelled to Asia Minor and Scythia, Georgia, Romania, along the Black Sea, up to the river Dnieper until he reached the site of future Kiev, which led to his reputation of being a patron saint of Russia, Ukraine and Romania. The scope of Andreas, however, is far more restricted, focusing on St Andrew's adventures in Mermedonia, the country of Man-Eaters. According to the poem, St Andrew is commanded by God to rescue St Matthew from captivity in Mermedonia into which he fell while trying to convert its heathen inhabitants. After some initial reluctance Andrew sails to the country on the ship manned by Jesus himself, whom Andrew recognises only after waking up on the shores of Mermedonia. On arriving in this country, he rescues St Matthew and other captives languishing in the Mermedonian prison and suffers the tortures inflicted on him by the frustrated and starved Mermedonians who are exhorted by the devil to murder him. The devil's attempt fails and numerous miracles performed by the saint, for example, the release of enormous quantities of water from a pillar in the Mermedonian prison which floods the city, the erection of a fire wall which prevents the Mermedonians from leaving the flooded place and their miraculous revival after their collective death in the flood, eventually convince the Mermedonians to reject paganism and accept Christianity.

\section{HEROIC CONCEPTS AND IDIOMS IN ANDREAS}

Andreas owes much of its scientific visibility to its juxtaposition of Germanic heroism and Christian martyrdom (Kiser, 65), its application of traditional poetic idioms to Christian topics, and its ability to adapt Germanic poetic heritage to the new world of Christianity, which leads us to the central purpose of this paper: to examine the function of a restricted number of traditional heroic concepts in the hagiographic context of the poem. Andreas in reality contains many elements typical of traditional heroic poetry which had existed among the Anglo-Saxons long before they adopted Christianity and whose prevailing themes had been war, warfare, weapons, the birds of prey, generous leaders, faithful retainers, the life in a lord's hall and distribution of gifts. The poetic vocabulary was full of terms describing such subjects (Toller, 109), as attested by surviving examples of Old English heroic poetry, such as Beowulf, The Finnsburg Fragment, The Batttle of Brunnaburh and The Battle of Maldon. Beowulf, in particular, is regarded as the most valuable and detailed example of Old English heroic poetry. Early scholars were so struck by the wealth of topics relating to the life of Germanic heroic society that they declared the poem to be "in its subject matter so independent of Christianity that it might be taken as a fair representative of the old native poetry" (Toller, 110).

Later scholarship, by contrast, has pointed out that Beowulf was composed by a Christian writer well trained in classical and Christian literary traditions, and this predominantly Christian orientation left such a distinguishing mark on the poem (Wrenn, Bolton, 51; Burrow, 10) that Beowulf can be seen as a Christian reconstruction of preChristian Germanic society (Donahue, 56). It can be argued, however, that in spite of its considerable foreign Christian element and its prevailing Christian perspective, the 
poem definitely focuses on a society which was dominated by traditional heroic values, such as the so-called comitatus relationship or the bond between the lord and his retainers, heroism, loyalty and physical endurance. In order to word properly such concepts, traditional heroic poetry created a number of conventional poetic idioms, poetic formulas and formulaic expressions which took such firm roots in the Old English poetic tradition that they were later retained and reused by the new Old English Christian poetry when recounting the deeds of saints, apostles and heroes from the Old and the New Testament (Toller, 109; Riedinger, 284; Bolton, Wrenn, 26). As a result, due to a significant impact of traditional heroic concepts and poetic idioms on Christian poetry, many Old English Christian poems reveal a higher or a lower degree of interaction between the worlds of traditional heroic society and Christianity.

Andreas is therefore hardly unique in its tendency to exploit traditional heroic concepts and imagery. The issue which causes so much scholarly dissension, however, is the nature of the poem's indebtedness to the Old English traditional poetic vocabulary. In other words, the scholars disagree on the question to what degree Andreas owes its traditional poetic diction to the common Old English poetic tradition and to what extent it is indebted for its traditional diction to one particular traditional heroic poem, Beowulf, which is in reality verbally and stylistically very close to Andreas. ${ }^{2}$ In fact, it is the existence of close verbal and stylistic parallels between both poems which has provoked most scholarly responses, both negative and positive. The first group of Anglo-Saxonists, mostly early critics as well as some contemporary scholars, have argued that Andreas is not a very successful imitation of Beowulf, Andreas's evocation of a substantial set of images from Beowulf being in their opinion incongruous and misplaced $^{3}$, while another group of scholars is more inclined to view the parallels and verbal similarities between both poems as an asset rather than liability. According to this positive scholarly opinion, the Andreas-poet reused Beowulf's images and verbal echoes relating to the life of traditional secular society in a creative and original way (Friesen, 239-240) as, by transferring them from their original environment of secular epic into a hagiographic context of his own poem, he managed to juxtapose the worlds of the ancient pagan society and Christianity, enabling thus his audience to compare the mentality of their pagan ancestry with their own Christian values.

Even though this paper also juxtaposes traditional images and heroic concepts occurring in both poems, this is never done with the purpose of taking part in the aforementioned debates concerning the nature of Andreas's reliance on traditional heroic diction which could be, according to the scholarship, obtained either via common poetic tradition or via Beowulf. The paper's only purpose is to discuss the function of a very restricted number of heroic concepts and related poetic vocabulary in Andreas: a) martial imagery relating to Andrew and his apostles, b) the concept of exile, c) the comitatus relationship and d) the hall-life, and comment on how far the poet succeeded in reusing the conventional secular topics and traditional poetic idioms in the context of hagiography. In order to determine the degree of Andreas' reliance on traditional heroic

\footnotetext{
${ }^{2}$ For a survey of scholarly opinions on this issue, see, for example, Cherniss, 173-174, Riedinger, 285288, Friesen, 107-123.

${ }^{3}$ For a further survey of these earlier views on Andreas, see Simpkins, 4-6, for the survey of contemporary scholarly opinions, see again Simpkins, 7-9.
} 
concepts and vocabulary, Beowulf as the most detailed example of preserved heroic poetry is simply too precious to be ignored as a point of departure for further comparisons in this direction even if there were no attested parallels between both poems.

\section{A. Martial imagery}

Beowulf abounds in the traditional poetic imagery relating to various aspects of life in traditional heroic society, with the martial images naturally occupying a central position in the narrative. The poem in its introductory lines glorifies the ancient kings of Denmark and their martial reputation:

$$
\begin{aligned}
& \text { HWÆT, WĒ GĀR-DEna in gēardagum, } \\
& \text { pōodcyninga prym gefrūnon, } \\
& \text { hū đa æðelingas ellen fremedon! }{ }^{4} \text { (ed. Klaeber, 11. 1-3) }
\end{aligned}
$$

Their strength, however, during the reign of Hrothgar no longer suffices to repel cannibal monsters disrupting Heorot, Hrotgar's royal hall, which stimulates Beowulf and his companions, the Geats, to sail across the sea and restore order in the palace. They are depicted as: cempan pāra be hē [Beowulf] cēnoste findan mihte (206-207b) - the boldest warriors he [Beowulf] could find, searo-haebbendra (237b) - the ones having armours, lind haebbende 245a) - shield bearers, gūð-fremmendra (246a) - battle-doers, fyrdhwate - brave in war (1641), to mention only a handful of examples. In the hagiographic context of Andreas the poet recalls in the opening lines the fame of the apostles in a similar martial manner: tireadige hæleð (glorious heroes), peodnes pegnas (the thanes of a prince), frome folctogan (bold chieftains), fyrdhwate (those bold in battle), rofe rincas (brave heroes):

HWÆT, we gefrunan on fyrndagum
twelwe under tunglum tireadige hæleð
peodnes ðegnas. No hira prym alæg
cam[p]rædenne, ponne cumbol hneotan
syððan hie gedældon swa him dryhten sylf,
heofona heahcyning, [h]lyt getæhte.
pæt wæron mære men ofer eorðan,
frome folctogan ond fyrdhwate,
rofe rincas ponne rond ond hand
on herefelda helm ealgodon,
on meotudwange; (ed. Brooks, 1l. 7-11).

${ }^{4}$ All the quotations are taken from F. Klaeber, ed., Beowulf and The Fight at Finnsburg, third edn. (Boston, 1950). All the translations are taken from: Benjamin Slade, BEOWULF. diacritically-marked text and facing translation, http: //www.heorot.dk/beo-intro-rede.html.

Translation: Listen! We of the Spear-Danes in the days of yore, of those clan-kings heard of their glory, how those nobles performed courageous deeds!

${ }^{5}$ All the translations of the passages from Andreas are taken from: Charles W. Kennedy, Andreas, Old English Series, Cambridge, Ontario, 2000; http://www.yorku.ca/inpar/Andreas_Kennedy.pdf.

Translation: Lo! We heard of twelve glorious men in olden days under the stars, the thanes of God; nor 
Apart from that, Matthew the Evangelist, though a man of learning and no military man at all, is also seen as a warrior who must often undergo suffering on the battlefield, and the poet says that "oft him bonena hand // on herefelda / hearde gesceode" (11. 17b-18). ${ }^{6}$

Both Beowulf and Andreas therefore exploit the same stock of heroic idioms and concepts: glory, brave warriors, famous in the days of yore, loyal and disciplined - the concepts with unmistakenly positive heroic connotations in both poems. Nevertheless, a close reading reveals that their heroism is based on different principles. Beowulf and his companions are primarily motivated by secular considerations: a sincere wish to assist the elderly king is combined with their love of glory, while Andrew's mind is bent on more spiritual concerns: the liberation of St Matthew and other captives, and the conversion of pagan Mermedonians. In order to achieve this objective, however, he is, unlike Beowulf, not expected to wield military weapons on a battlefield, being intent on using other, spiritual devices instead: patience, fortitude, stoicism with which he endures tortures inflicted on him, prayer and miracles, all of which can be classified as spiritual weapons. ${ }^{7}$ In other words, Beowulf and his companions are secular heroes engaged in armed conflicts, while Andrew and his apostles are spiritual soldiers, saints, missionaries, soldiers of Christ, milites Christi, and it is their Christianity and saintly mission which make them superior to any secular hero of the pagan Germanic past. The traditional military terminology used to denote their spiritual endeavours must be therefore understood metaphorically, serving as a visual presentation of their spiritual struggle. ${ }^{8}$

The pagans whom Andrew is commanded to convert are also depicted as soldiers: "Duguð samnade, // hæðne hildfrecan / heapum prungon // guðsearo gullon / garas hrysedon bolgenmode // under bordhreoðan." (11. 125a-128) $)^{9}$, but in reality their military activities are limited to guarding prisoners who are destined to be slaughtered after their captivity of thirty days. This discrepancy between traditional heroic images used in their traditional heroic and secular environment of Beowulf and their reuse in Andreas is even more apparent if we juxtapose the actions of Mermedonians on one side:

did their glory fail them in the fray when standards massed together, what time they were divided according as the Lord Himself, the high king of heaven, revealed to them their lot! And they were mighty men over the earth, brave leaders of the folk, bold in battle, stout of heart, when hand and buckler shielded the helm on the plain of war, on the field of fate.

${ }^{6}$ Translation: often the hand of murderous men smote him heavily upon the battlefield.

${ }^{7}$ For a view that the so-called Christian heroism could be exceptionally aggressive and, for example, 'equally concerned with the capture of territory as it is with the capture of souls' see Joy, 5-6.

${ }^{8}$ In fact, this mixture of spiritual and military heroism in Andreas is in line with the tendencies of early Christian writers who "often used the language of warfare to describe the continuous conflict between virtue and vice. Examples abound not only in the discourse of the Fathers of the early Church, but in the Scripture itself. The Benedictine Rule also capitalised on this concept, urging monks in the best martial tradition to behave as warriors participating in armed combat. Service and obedience to God were construed as weapons and the entire membership of the monastic movement was metaphorically conscripted into a "holy army". Even martyrdom, the ultimate expression of non-violence, was regarded as a "conquest of the devil", and thus took a central place in God's arsenal" (Simpkins, 28-29). For an additional view, see also Irving Jr.: "...so long as the two central virtues of courage and obedience are what is stressed, it is not hard to accept attribution of these virtues to both warriors and missionaries [in Andreas], with helmets, banners and spears merely the symbols of militant dedication in the face of death" (216).

${ }^{9}$ Translation: The host assembled, heathen battle-wolves gathered in throngs, armour rang, spears shook, and under the shelter of shields the hearts were wroth. 
Pa gesamnedon side herigeas, folces frumgaras; to pam fæstenne wærleasra werod wæpnum comon, hæðne hildfrecan, to pæs pa hæftas ær under hlinscuwan hearm prowedon. (11. 1067-1071) ${ }^{10}$

and Beowulf and his companions on the other: " /byrnan hringdon, // gupsearo gumena; / garas stodon, // sæmanna searo samod ætgaedere, //æscholt ufan græg / wæs se irenpreat // wæpnum gewurpad (Beowulf, 327b-31a) ${ }^{11}$ Both passages are reminiscent of the armed men gathering to discuss a plan of attack (Simpkins, 54), but there is a striking difference between Beowulf and his companions, who are getting ready to meet Hrothgar, and the Mermedonians, who are getting ready to slaughter their captives in the prison.

The impression that the traditional poetic diction used to denote Mermedonians as warriors no longer retains its traditional heroic meaning is further confirmed, for example, by the following image: " .... beornas common, // wiggendra preat, / wicgum gengan, // on mearum modige, / mæðelhegende, // æscum dealle" (1094b-1097a). ${ }^{12}$ One would expect these fine Mermedonian warriors to rush into the battle, but all their activities are limited to casting lots to decide whom of the Mermedonians to consume instead of their prisoners rescued by the saint. Their actions are so vile and pseudo-heroic that the military imagery applied in this context functions as a gruesome parody and it can be argued that the Andreas-poet consciously manipulates the traditional heroic imagery in such a way as to underline a grotesque and bizarre nature of the Mermedonian inhabitants, ${ }^{13}$ making the difficulties of Andrew's missionary task all the more apparent.

\section{B. Exile}

Andrew's initial reluctance to travel to Mermedonia and obey his Lord unconditionally seems incredible at first sight. ${ }^{14}$ But Andrew's reaction is perfectly explainable in the eyes of the poet's Anglo-Saxon audience as Andrew's mission is described as a kind of exile, the departure to a foreign land, an event feared by any Germanic hero

${ }^{10}$ Translation: And mighty multitudes assembled, leaders of the folk, unto the prison came a horde of faithless men with weapons, heathen heroes, to where their prisoners suffered woe afore time, within the darkness.

${ }^{11}$ Translation: corslets rang, the war-clothes of warriors; spears stood, seamen's weapons, all together silvery above a grove of ash, the iron-clad troop was honoured in weapons.

${ }^{12}$ Translation: Heroes came, a throng of warriors on their chargers, upon their steeds, men stout of heart, and counsellors strong with the spear.

${ }^{13}$ See again Irving Jr.: "Travesty and parody must again be drawn in to relate the Mermedonians' strange actions to the heroic atmosphere of the poem. What they did is necessarily depicted as mock-heroic. .... Only the term 'mock-heroic' could describe what follows, an account of frenzied military preparation by the entire army for the butchery of the defenceless boy, whose plight is presented affectingly" (229-230). See also Simpkins, p. 54: "Indeed, the poet implies that the Mermedon version of heroic aggression is almost comic."

${ }^{14}$ Andrew is in reality a rather reluctant saint, the fact which had been noticed already in the past and which had caused a considerable amount of uneasiness among early medieval hagiographers (DeGregorio, 454-455). 
because exile meant the abandonment of a native land, separation from relatives, social degradation, poverty and hardship (Cherniss, 185), this suffering being in most cases the result of a tribe's defeat after the death of their lord and protector. Thus in Beowulf it is pointed out that after Beowulf's death his tribe of the Geats faces a disaster, the disintegration of their social life and the abandonment of their native land:
nē mægð scyne
habban on healse hring-weorðunge, ac sceal geōmor-mōd, holdne berēafod, oft, nalles æne, eland tredan (1l. 3016b-3019). ${ }^{15}$

It is therefore understandable that Andrew, even though commanded by God himself to travel to Mermedonia and rescue St Matthew, is not exactly keen on obeying this command, suggesting instead that the Lord's angel might be a better man for the job:

Hu mæg ic, dryhten min, ofer deop gelad

fore gefremman on feorne weg swa hrædlice, heofona scyppend, wuldres waldend, swa ðu worde becwist?

Đæt mæg engel pin eað geferan, $<$ halig $>$ of heofenum; con him holma begang, sealte sæstreamas ond swanrade, waroðfaruða gewinn ond wæterbrogan, wegas ofer widland. Ne synt me winas cuðe, eorlas elpeodige, ne pær æniges wat hæleða gehygdo, ne me herestræta ofer cald wæter cuðe syndon (11. 190-201). ${ }^{16}$

The sea separating Andrew's present abode from the land of cannibals is marked by a number of conventional formulaic expressions, such as holma begang (circuit of oceans), sealte streamas (salty ocean-streams), swanrad (swan-road), waroðfaruða gewinn (tumult of the surf), wæterbrogan (terrible waters) and most importantly, cald wæter (cold sea-water) which further confirm a frightening nature of his projected voyage. ${ }^{17}$ Later Andrew is provided with some further information concerning his duties in Mermedonia where the emphasis is again on a risk-taking mission described in heroic terms. Thus he must expect a battle: guðgewinn (conflict), hæðenra hildewoman (heathens' tumult of war), beorna beaducræft (battle-craft of followers), the martial images symbolizing his spiritual fight:

\footnotetext{
${ }^{15}$ Translation: no pretty girl shall have on her neck ring adornment, but must, sad-hearted, bereft of gold, often, not once, tread in alien land.

${ }^{16}$ Translation: How may I journey on so distant way, over the deep sea-path thus speedily, O my God, Thou Lord of Heaven, Wielder of glory, as Thou dost say? That may Thine angel from heaven easily attain. For he knoweth the compass of the seas, the salty ocean-streams, the swan-road and the tumbling surges, the tumult of water floods, and ways across wide lands. No friends are known to me among those alien earls, neither do I know the heart of any man, nor are the ways across the cold sea-water known to me a whit.

${ }^{17}$ For a survey of nautical images in Old English poetry, Christian and heroic, see Orchard, 298-302, who at the same time lists a number of Latin authors using the image of a dangerous sea journey as a broader metaphor for human life which must be, like a ship, brought into a safe harbour (303).
} 
Đu scealt pa fore geferan ond pin feorh beran

in gramra gripe, ðær be guðgewinn

purh hæðenra hildewoman,

beorna beaducræft, geboden wyrðeð.

Scealtu æninga mid ærdæge,

emne to morgene, æt meres ende

ceol gestigan, ond on cald wæter

brecan ofer bæðweg (11. 216-223a). ${ }^{18}$

Apart from this vision of Mermedonia as a land of heroic exile, ${ }^{19}$ there are two other interpretations which further demonstrate the poet's ability to use traditional and concrete terms in such a way as to make them increasingly more suggestive of their abstract and allegorical meaning (Hamilton, 150-151): Mermedonia as a land of spiritual exile and Mermedonia as an image of hell. According to the first interpretation, Andrew and Matthew can be seen as exiles, literally and spiritually, "as actual missionary peregrini and loyal followers of Jesus, they sojuourn in a foreign land where their stay is charaterized by social isolation and religious persecution" (Simpkins, p. 22). At the same time, their exile can be viewed from a broader perspective of the transience of human life: our life in this temporal world must be understood as a kind of exile until we eventually find our true home in heaven. As noted by numerous scholars, Mermdonians also live in a state of exile being isolated from the rest of mankind, the servants of Satan, whose paganism brings them nothing but misery and their barren land which fails to bear any fruit symbolizes their material and spiritual wretchedness (Hamilton, 151).

According to the other interpretation, supported in particular by Constance Hieatt, Mermedonia is even a more sinister place, symbolizing hell and Andrew's travel there is to be understood as the descent into hell, and the sea denoted by so many traditional synonyms and formulaic expressions is the road to hell. The idea that Andrew's journey to Mermedonia can be interpreted as the descent into hell is based on narrative typology and figural history, the early medieval doctrine which interpreted the actions of saints as the imitation of Christ, and the more faithfully their deeds resembled those of Christ, saints and biblical heroes the higher position they held in the family of saints (Rollason, 5). Andrew's suffering and tortures inflicted on him for three days in the prison, which is metaphorically a grave, and his release from it are, according to narrative typology, reminiscent of the Passion of Christ and his Resurrection (Hieatt, 52-53).

\section{The comitatus relationship}

The loyalty to one's lord was regarded as the main virtue in heroic society and the heroes who broke this bond were held in general contempt. It is therefore not surprising that the followers are determined not to part with Andrew even though they find the

\footnotetext{
${ }^{18}$ Translation: Thou shalt fare forth and bear thy life unto the clutch of cruel men, when strife of contest will be offered, with shout of heathen warriors and battle-craft of heroes. Straight with early day, just at the dawn, at the sea's strand, thou shalt ascend thy ship and on the chill floods plunge o'er the ocean path.

${ }^{19}$ According to Brady, Mermedonia in Andreas is modelled on the fens in Anglo-Saxon England settled by the British population which was in classical geographies associated with ritual cannibalism (682-683).
} 
sea voyage so hard to endure that they fall sick during the journey and they are given a chance to be taken ashore. Their refusal to abandon their lord is worded in traditional terms of the comitatus relationship, the bond between the lord and his retainers based on mutual trust and respect (Irving Jr., 223; Cherniss: 187-188):

Hwider hweorfað we hlafordlease,
geomormode, gode orfeorme,
synnum wunde, gif we swicað pe?
We bioð laðe on landa gehwam,
folcum fracoðe, ponne fira bearn,
ellenrofe, æht besittap,
hwylc hira selost symle gelæste
hlaforde æt hilde, ponne hand ond rond
on beaduwange billum forgrunden
æt niðplegan nearu prowedon (11. 405-414). ${ }^{20}$

The Andreas-poet's ability to manipulate heroic conventions in such a way as to make abstract Christian concepts easier to understand becomes even more apparent when this scene is juxtaposed with a similar passage in Beowulf, in which Wiglaf, Beowulf's most loyal retainer, expresses his contempt at Beowulf's retainers who deserted their lord during his fight with the dragon:
Hū sceal sinc-pego ond swyrd-gifu, eall ēðel-wyn ēowrum cynne, lufen ālicgean; lond-rihtes mōt pære mæg-burge monna æghwylc īdel hweorfan, syððan æðelingas feorran gefricgean flēam ēowerne, dōm-lēasan dæd. Dēað bið sēlla eorla gehwylcum ponne edwìt-lîf! (11. 2880-2891) ${ }^{21}$

Both Beowulf and Andreas cherish the concept of loyalty which is in both poems embedded in traditional poetic expressions, although with two essential differences. First, in Beowulf, Wiglaf and his companions obey a secular master, while Andrew and his retainers serve the highest lord of heaven and earth, and second, if in Beowulf the retainers fail their lord, in Andreas they remain loyal, which additionally stresses the superiority of Christ's soldiers to any secular comitatus.

At a literal level Andrew is charaterized as a traditional military leader surrounded by devoted followers. At a metaphoric level, however, Andreas can be regarded as a tale of discipleship, the bond between Andrew and his companions being reminiscent of the relationship between Christ, often depicted as a teacher, and his apostles. In fact, in the

\footnotetext{
${ }^{20}$ Translation: Whither may we turn without a lord, soul-sorrowful, empty of good, wounded with sin, if we depart from thee? For we are hated in every land, of any fold abhorred when stalwart sons of men hold counsel, which of them hath ever best upholden thir lord in battle, when hand and shield upon the plain of war, hacked with swords, in the sport of strife, suffered heavy hardship.

${ }^{21}$ Translation: How must treasure-receipt and sword-giving, all native joy for your kin, delight cease! Of land-rights must of your clan every man become deprived, when nobles from afar learn of your flight, gloryless deed: death is better for all men than life of dishonour!
} 
poem, Andrew's teaching activity is referred to several times: first in Achaia where he preaches before his departure to Mermedonia, then on board with Jesus and angels, and finally in Mermedonia when the inhabitants are eventually willing to respond positively to Andrew's missionary endeavours (Kiser, 66-67). The sea journey can be interpreted as a kind of intellectual testing where Andrew must answer correctly Christ's questions relating to various aspects of Christianity - in other words, he must prove his orthodoxy and his ability to preach - and only then he is allowed to start teaching in Mermedonia (Kiser, 68; Cherniss, 187; Hamilton, 154-155). To sum up, in Andreas the traditional concept of the comitatus relationship has been modified to obtain a new, Christian association, that of a spiritual bond between a prophet and his disciples, serving as another example of Andrew's imitation of Christ.

\section{The hall-life}

The hall-life was one of central motifs in Old English traditional poetry, the hall being a symbol of prosperity, security, friendship, royal splendour and dignity where the generosity in the distribution of gifts occupies a central position:

heal-æ,rna mæst; scōp him Heort naman,
sē pe his wordes geweald wīde hæfde.
Hē bēot ne ālēh, bēagas dælde,
sinc æt symle. Sele hlīfade
hēah ond horn-gēap, heaðo-wylma bād,
lāðan līges; ne wæs hit lenge pā gēn,
pæt se ecg-hete āpum-sweoran
æfter wæl-nīðe wæcnan scolde (11. 78-85). ${ }^{22}$

In Beowulf, the destruction of Heorot is explained as a consequence of a family feud and another passage from Beowulf - even though not referring to Heorot - is also suggestive of the violence and destruction which were a common lot of each military society:

Næs hearpan wyn,
gomen glēo-bēames, nē gōd hafoc
geond sæl swingeð, nē se swifta mearh
burh-stede bēateð. Bealo-cwealm hafað
fela feorh-cynna forð onsended! (11. 2262b-2266) ${ }^{23}$

Nevertheless, even though the hall-life in Beowulf is presented as fragile and temporary, the halls of ancient kings stand for everything that is dignified, courtly and

\footnotetext{
${ }^{22}$ Translation: the best of royal halls, he named it Heorot, he whose words weight had everywhere, he did not lie when he boasted; rings he dealt out, riches at his feast. The hall towered, high and horn-gabled, it awaited the cruel surges of hateful flames, nor was the time yet nigh, that the furious edge-malice of the son-in-law and father-in-law, arising from deadly enmity would inevitably awaken.

${ }^{23}$ Translation: there was no harp's joy, delight of glee-wood, nor good hawk soaring through the hall, nor swift horse trampling the courtyard; baleful death has many of the living kin sent forth.
} 
positive in the world of heroic society (Hume, 66-67). The halls in Mermedonia, by contrast, are no longer seen as places of dignified enjoyment. The frustrated and starving Mermedonians are so obsessed with the thought of food that they lose all their interest in the hall-life nor do they care for their treasures any longer: "næs him to maðme wynn, // hyht to hordgestreonum.' (11. 1113-1114) - they had no joy in treasure, no delight in precious things - and as a result of famine, their halls are left deserted (Cherniss, 184; Irving Jr., 230):

Pa wæs wop hæfen in wera burgum, hlud heriges cyrm; hreopon friccan, mændon meteleaste, meðe stodon hungre gehæfte. Hornsalu wunedon weste, winræced; welan ne benohton beornas to brucane on pa bitran tid (11. 1155-1160). ${ }^{24}$

The abandoned halls symbolise social disintegration of the Mermedonian society which must pay the price for its paganism and obedience to Satan by being struck by famine which nearly forces the Mermedonians to resort to the most abominable kind of cannibalism: eating their own children. According to the Old Testament, cannibalism is a curse placed on a nation for having turned its back on God, who punishes them with such severe famine that they are turned into cannibals eating their own children (Ezekiel 5:10, Jeremiah 19:9, Lamentations 4:9-10), the crime, which would have been committed in Mermedonia as well if St Andrew had not intervened in time (1l. 1108-1116a). The Mermedonians' cannibalism can be explained as a kind of punishment for their paganism which they must abandon and accept Christianity before they are eventually forgiven (Casteen, 77-78; Godlove, 142-143; Bolintineanu, 162).

The halls, even though magnificent and finely built, cannot be a source of pleasure in the society ruled by Satan and it is only at the end of the poem when St Andrew succeeds in converting the inhabitants that the Mermedonians and their halls are allowed to be seen in a positive light, as a symbol of the reformed Mermedonian society:

Sægde his fusne hige,

pæt he pa goldburg ofgifan wolde,

secga seledream ond sincgestreon,

beorht beagsealu , ond him brimpisan

æt sæs faroðe secan wolde (11. 1654b-1658). ${ }^{25}$

The vocabulary employed in this passage to praise the reformed Christian Mermedonia could be used without any reluctance in the context of an ideal heroic society where halls are depicted as centres of well-regulated social life (Garner, 61). The lines also suggest that Andrew's task has been successfully accomplished and that he is finally free to return to Achaia leaving behind a peaceful and Christian country.

\footnotetext{
${ }^{24}$ Translation: Wailing was lifted up in the cities of men, loud lamentation of the host. Heralds cried aloud, men meatless mourned, and sad of heart stood round about, fast in the bonds of hunger. Empty abode the gabled dwelling, wine-halls. Nor any weal had men to joy in at that bitter hour.

${ }^{25}$ Translation: He spake his mind to leave them, that he would fain quit that gold-burg, the revelry of men and store of treasure, and bright song-halls, and on the sea-strand seek a ship.
} 


\section{CONCLUSION}

This paper discusses four examples of the interaction between the world of traditional Germanic society on one hand and the world of Christianity on the other. As a result, it would be unwise to make too general conclusions on the basis of such a small sample. Nevertheless, it is safe to argue that the selected examples of traditional heroic concepts are in Andreas reused in a new Christian context in an artistically convincing way and that the traditional diction is successfully subjected to the poem's Christian theme. It can also be pointed out that in the four examples discussed in this paper the Andreas-poet has successfully managed to juxtapose the Christian and heroic worlds, express metaphorical Christian concepts in the traditional form of heroic verse and make abstract Christian ideas comprehensible by using a number of concrete traditional poetic images.

Novo mesto, Slovenia

\section{WORKS CITED}

Abdou, Angela. "Speech and Power in Old English Conversion Narratives". Florilegium 17, 2000: 195-212.

Aleksander, Michael. Old English Literature. London: Macmillan, 1983.

Biggs, Frederick M. “Ælfric's Andrew and the Apocrypha”. Journal of English and Germanic Philology 104, 2005: 473-494.

Bjork, Robert E. The Old English Verse Saints'Lives. Toronto: Toronto UP, 1985.

Boenig, Robert E. "Andreas, the Eucharist, and Vercelli". Journal of English and Germanic Philology 79, 1980: 313-331.

Bolintineanu, Alexandra. "The Land of Mermedonia in the Old English Andreas". Neophilologus 93, 2009: 149-164.

Brady, Lindy. "Echoes of Britons on a Fenland Frontier in the Old English Andreas". The Review of English Studies 61, 2010: 669-689.

Brooks, Kenneth R (ed.). Andreas and The Fates of the Apostles. Oxford: Clarendon Press, 1961.

Burrow, J. A. "Old and Middle English". In Pat Rogers (ed.), The Oxford Illustrated History of English Literature. Oxford/New York: Oxford UP, 1987.

Casteen, John. "Andreas. Mermedonian Cannibalism and Figural Narrative". Neuphilologische Mitteilungen 75, 1974: 74-78.

Cavill, Paul. "Beowulf and Andreas: Two Maxims". Neophilologus 77, 1993: 479-487.

Cherniss, Michael D. Ingeld and Christ: Heroic Concepts and Values in Old English Christian Poetry. The Hague-Paris: Mouton, 1972.

Crowne, David K. "The Hero on the Beach. An Example of Composition by Theme in Anglo-Saxon Poetry". Neuphilologische Mitteilungen 61, 1960: 557-561.

Davis, Graeme. "Beowulf's Debt to Andreas". Journal of Language and Literature 1, 2002: 23-27.

DeGregorio, Scott. "Pegenlic or flæsclic: The Old English Prose Legends of St. Andrew". Journal of English and Germanic Philology 102, 2003: 449-464.

Donahue, Charles. "Beowulf and Christian Tradition: A Reconsideration from a Celtic Stance". Traditio 21, 1965: 55-116.

Frisen, Bill. Visions and Revisions: The Sources and Analogues of the Old English Andreas. A thesis submitted in conformity with the requirements for the degree of Doctor of Philosophy, Graduate Department of English, University of Toronto, 2008. 
Gardner, John. The Construction of Christian Poetry in Old English, Literary Structures: History and Criticism 3. Carbondale and Edwardsville: Southern Illinois University Press, 1975.

Garner, Lori Ann. "The Old English Andreas and the Mermedonian Cityscape". Essays in Medieval Studies 24, 2007: 53-63.

Gober, Wallace G. “Andreas, lines 360-362”. Neuphilologische Mitteilungen 73, 1972: 672-674.

Godden, Malcolm, and Michael Lapidge (eds.), The Cambridge Companion to Old English Literature. Cambridge: Cambridge UP, 1975.

Godlove, Shannon N. "Cannibalism and Conversion in the Old English Andreas". Studies in Philology 106, 2009: 137-160.

Hamilton, David. "The diet and digestion of allegory in Andreas". Anglo-Saxon England 1, 1972: 147-158.

Hieatt, Constance B. “The Harrowing of Mermedonia”. Neuphilologische Mitteilungen 77, 1976: 49-62.

Hill, Joyce. "The Soldier of Christ in Old English Prose and Poetry". Leeds Studies12, 1980-81: $57-74$

Hill, Thomas D. "Figural Narrative in Andreas. The conversion of Mermedonians". Neuphilologische Mitteilungen 70, 1969: 261-273.

Hill, Thomas D. "Hebrews, Israelites, and Wicked Jews: an Onomastic Crux in 'Andreas' 161-167". Traditio 32, 1976: 358-361.

Hume, Kathryn. "The concept of hall in Old English". Anglo-Saxon England, 3, 1974: 63-74.

Irving, Edward B. Jr. "A reading of Andreas: the poem as poem". Anglo-Saxon England 12, 1983: 215-237.

Kabir, Ananya J. "Towards a Contra-Modern Aesthetics. Reading the Old English Andreas Against an Image of the Virgin of Guadalupe". In Ananya J. Kabir and Deanne Williams (eds.), Postcolonial Approaches to the European Middle Ages: Translating Cultures. Cambridge, Eng.: Cambridge UP, 2005:

Kiser, Lisa J. "Andreas and the lifes weg. Convention and Innovation in Old English Metaphor". Neuphilologische Mitteilungen 85, 1984: 65-75.

Joy, Eileen A. "Strange Encounters: Andreas, Time-Knots, and Reparative Readings", http://www. siue.edu/ ejoy/AndreasAfterword.htm. Retrieved on 28 September 2011.

Nicholson, Lewis E., and Dolores Warwick Frese, (eds.), Anglo-Saxon Poetry: Essays and Appreciation. Notre Dame, Indiana: University of Notre Dame Press, 1975.

Orchard, Andy. "The Word Made Flesh: Christianity and Oral Culture in Anglo-Saxon Verse". Oral Tradition 24/2, 2009: 293-318.

Rollason, D. W. (ed.), Vita Deo Dilectae Virginis Mildrethae, in The Mildrith Legend: A Study in Early Medieval Hagiography in England. Leicester: Leicester University Press, 1982: 104-143.

Riedinger, Anita R. "Formulaic Relationship between Beowulf and Andreas". In Helen Damico and John Leyerle (eds.), Heroic Poetry in the Anglo-Saxon Period. Studies in Honour of Jess B. Bessinger Jr. Kalamazoo, Mich.: Medieval Institute Publications, 1993: 283-312.

Siewers, Alfred K. "Landscapes of Conversion: Guthlac's Mound and Grendel's Mere as Expressions of Anglo-Saxon Nation Building". In Eileen A. Joy and Mary K. Ramsey (eds.), The Postmodern Beowulf. West Virginia University Press, 2006: 199-257.

Simpkins, Linda Margaret. The Role of Martial Diction and Beowulf Borrowings in OE Andreas. A Thesis Submitted in Partial Fulfillment of the Requirements for the Degree of Master of Arts in the Faculty of Graduate Studies, University of the British Columbia, 1985.

Swanton, Michael. English Literature before Chaucer. London: Longman, 1987.

Swisher, Michael. "Beyond the Hoar Stone”. Neophilologus 86, 2002: 133-136.

Toller, T. N. History of the English Language. Cambridge: Cambridge UP, 1904.

Walsh, Marie M. "St Andrew in Anglo-Saxon England: The Evolution of an Apocryphal Hero". Annuale mediaevale 20, 1981: 97-122.

Wilson, James H. Christian Theology and Old English Literature. The Hague and Paris: Mouton, 1974. 
Woolf, Rosemary. “Saints' Lives”. In Eric Gerald Stanley (ed.), Continuations and Beginnings. Studies in Old English Literature. London: Nelson, 1966: 37-66.

Wrenn, C. L., and Bolton W. F. Beowulf with the Finnsburg Fragment. Exeter: Exeter UP, 1988. 